\title{
Habitat use and conservation of an Endangered dolphin
}

\author{
Stephen Dawson ${ }^{1, *}$, David Fletcher ${ }^{2}$, Elisabeth Slooten ${ }^{3}$ \\ ${ }^{1}$ Department of Marine Science, ${ }^{2}$ Department of Mathematics and Statistics, and ${ }^{3}$ Department of Zoology, \\ University of Otago, PO Box 56, Dunedin, New Zealand
}

\begin{abstract}
We studied habitat use by Hector's dolphins Cephalorhynchus hectori in order to quantify the influences of location, season, time and tide, and to determine how frequently dolphins use inner Akaroa Harbour where unattended gillnetting is allowed for 6 mo of the year (1 April to 30 September). T-POD acoustic dataloggers were moored in outer, mid- and inner Akaroa Harbour to quantify variation in habitat utilisation by Hector's dolphins over a year. Acoustic detections were analysed via an information-theoretic approach, with model choices made via quasi-Akaike's Information Criterion. The best model included all 4 factors 'site', 'season', 'time' (since sunrise) and 'tide' (time since high tide) and 5 interactions (site $\times$ season, site $\times$ time, site $\times$ tide, season $\times$ time, season $\times$ tide). Of the interactions, site $\times$ season was most important, with seasonal differences being much greater in the inner harbour than elsewhere. Next most important was site $\times$ time after sunrise, suggesting diurnal movement of dolphins within the harbour. T-POD data showed a much higher level of use of the inner harbour in winter than was expected, indicating that the current compromise allowing gillnetting in this area poses a genuine risk of entanglement.
\end{abstract}

KEY WORDS: Hector's dolphin · Habitat use $\cdot$ Time $\cdot$ Tide $\cdot$ Season

\section{INTRODUCTION}

Understanding habitat use, and how it is influenced by natural physical features of the environment, is fundamental to ecology and conservation. For marine mammals, among the most obvious environmental correlates of habitat use and distribution are geographic location, season, time and tide. At a large scale, effects of geography and season are obvious; for example, some species are found solely in Arctic regions (e.g. polar bears Ursus maritimus, walrus Odobenus rosmarus, narwhal Monodon monoceros), and others undertake extensive seasonal migrations between fundamentally different habitats (e.g. humpback whales Megaptera novaeangliae, grey whales Eschrichtius robustus). The importance of these factors is clear also at a small scale. Many species have particular locations where they are most common, but are rarely seen in other, apparently similar, areas nearby (e.g. Childerhouse \& Gales 1998, Ingram \& Rogan 2002). For many species, this changes seasonally (e.g. Wilson et al. 1997, Verfuß et al. 2007). Patchiness, over a variety of scales and time periods, is a general feature of marine mammal distributions.

Studies of habitat use help to reveal important environmental influences on species. For example, several studies have related small-scale changes in distribution to time of day (e.g. Norris \& Dohl 1980, Würsig et al. 1991) or the state of the tide (Mendes et al. 2002). A variant of the latter is when animals congregate to forage on ephemeral tidal fronts (Johnston et al. 2005a,b). Habitat use is also of obvious relevance when spatial options are considered for conservation management (Bailey \& Thompson 2009). 
Many studies of habitat utilisation, and of the physical factors that influence it, have relied on data gathered via visual surveys (e.g. Bailey \& Thompson 2006). Electronic tagging has been used to document movement and habitat use by many marine animals (e.g. Polovina et al. 2004, Bonfil et al. 2005, Sveegaard et al. 2011, Maxwell et al. 2012), but its use, particularly with small cetaceans, poses dual difficulties of tag attachment and potential behavioural effects of the tag or tagging procedure (e.g. Schneider et al. 1998, Geertsen et al. 2004).

Moored echolocation detectors provide an alternative and have been used widely for documenting habitat use (e.g Akamatsu et al. 2010, Bailey et al. 2010), activity patterns (e.g. Carlström 2005), presence around fishing gear (Cox \& Read 2004), echolocation behaviour (Koschinski et al. 2008) and the potential impact of anthropogenic disturbance (e.g. Tougaard et al. 2009). The advantages of this approach include around-the-clock monitoring for extended periods, in adverse weather, lack of impact on the study species, and cost effectiveness. In our application of this approach, the principal disadvantage is that echolocation pulses can be detected reliably only over relatively short ranges (Tougaard et al. 2006, Rayment et al. 2009a, Akamatsu et al. 2010, Elliott et al. 2011, Kyhn et al. 2012).

Hector's dolphin Cephalorhynchus hectori is a small, endangered species endemic to the coastal waters of New Zealand. Bycatch in fisheries, particularly in gillnets (Dawson 1991, Gormley et al. 2012), is the most significant threat to the species (MPI/ DOC 2012). The species has a nearshore coastal distribution and is regularly present in the large harbours of Banks Peninsula. Individuals have relatively small alongshore home ranges (ca. $50 \mathrm{~km}$ ) and show high site fidelity (Rayment et al. 2009b). Distribution and abundance have been assessed nationwide via line-transect surveys (Dawson et al. 2004, Slooten et al. 2004). Habitat use has been investigated only via analysis of acoustic detections in 3 bays on Banks Peninsula.

Gillnet bycatch of Hector's dolphins is managed largely via restrictions on gillnet use in inshore waters. For example, off most of the South Island's east and south coasts gillnetting is currently illegal year-round out to 4 nautical miles (n miles) offshore (Slooten \& Dawson 2010). This management strategy was first adopted in 1988, when the Banks Peninsula Marine Mammal Sanctuary banned gillnetting within $4 \mathrm{n}$ miles of the shore. To pacify amateur gillnetters, the Department of Conservation compromised the fishing regulations in 1990, allowing unattended gillnetting for flatfish in the inner parts of Banks Peninsula's 4 largest harbours (Akaroa, Lyttelton, Port Levy, Pigeon Bay), for 7 mo of the year from 1 April to 30 September (Dawson \& Slooten 1993). There have been no temporal analyses of dolphin habitat use on a sufficiently fine scale to address the potential risk posed by this compromise.

Our purpose here was to document, over the course of a year, the small-scale habitat use of Hector's dolphins. We explored the effects of season, location, time, tide and their interactions via log-linear modelling of acoustic detection data gained from acoustic event recorders moored in the inner, mid- and outer Akaroa Harbour. We also used these data to reassess the risk posed by gillnetting for flatfish by amateur fishers, a practice known to result in Hector's dolphin mortalities (Dawson 1991).

\section{MATERIALS AND METHODS}

Echolocation detectors (T-PODs, 1 v.3 [No. 271], 2 v.4 [Nos. 484, 488]; Chelonia Ltd) were moored in Akaroa Harbour, Banks Peninsula in 3 locations from 16 February 2007 to 18 February 2008 (Fig. 1). The 3 locations were chosen to represent inner, middle and outer harbour sites. The inner site was $600 \mathrm{~m}$ from the nearest shore, on muddy substrate at a depth of ca. $6 \mathrm{~m}$. The mid-harbour site was on fine sand in a small embayment, about $150 \mathrm{~m}$ from shore at a depth of ca. $8 \mathrm{~m}$. The outer harbour site was ca. $30 \mathrm{~m}$ from a steep rock face, on a coarse sandy bottom at ca. $18 \mathrm{~m}$ depth. The tidal range at these sites is ca. $1.8 \mathrm{~m}$. The inner and outer sites also represent habitats typically used by amateur gillnetters in Akaroa Harbour and elsewhere in New Zealand. The inner harbour site is frequently used by amateur gillnetters (S. Dawson \& E. Slooten pers. obs.) targeting flatfish (predominantly Rhombolosea plebia and Peltorhamphus novaezeelandiae), and within the area where unattended gillnetting is seasonally legal. The outer harbour site was just outside the weed off a rocky shore, and is typical of areas elsewhere used by amateur netters targeting butterfish Odax pullus and moki Latridopsis ciliaris (S. Dawson \& E. Slooten pers. obs.). We have observed gillnets set in all 3 sites where T-PODs were deployed. T-POD 271 was used exclusively at the inner harbour site, while the other 2 T-PODs were swapped between outer and middle harbour sites on each service.

T-PODs were fastened to moorings so that the instrument was at a depth of ca. $5 \mathrm{~m}$. They were set to record continuously, serviced at 4 to $6 \mathrm{wk}$ intervals by diving, at which time they were removed, cleaned 


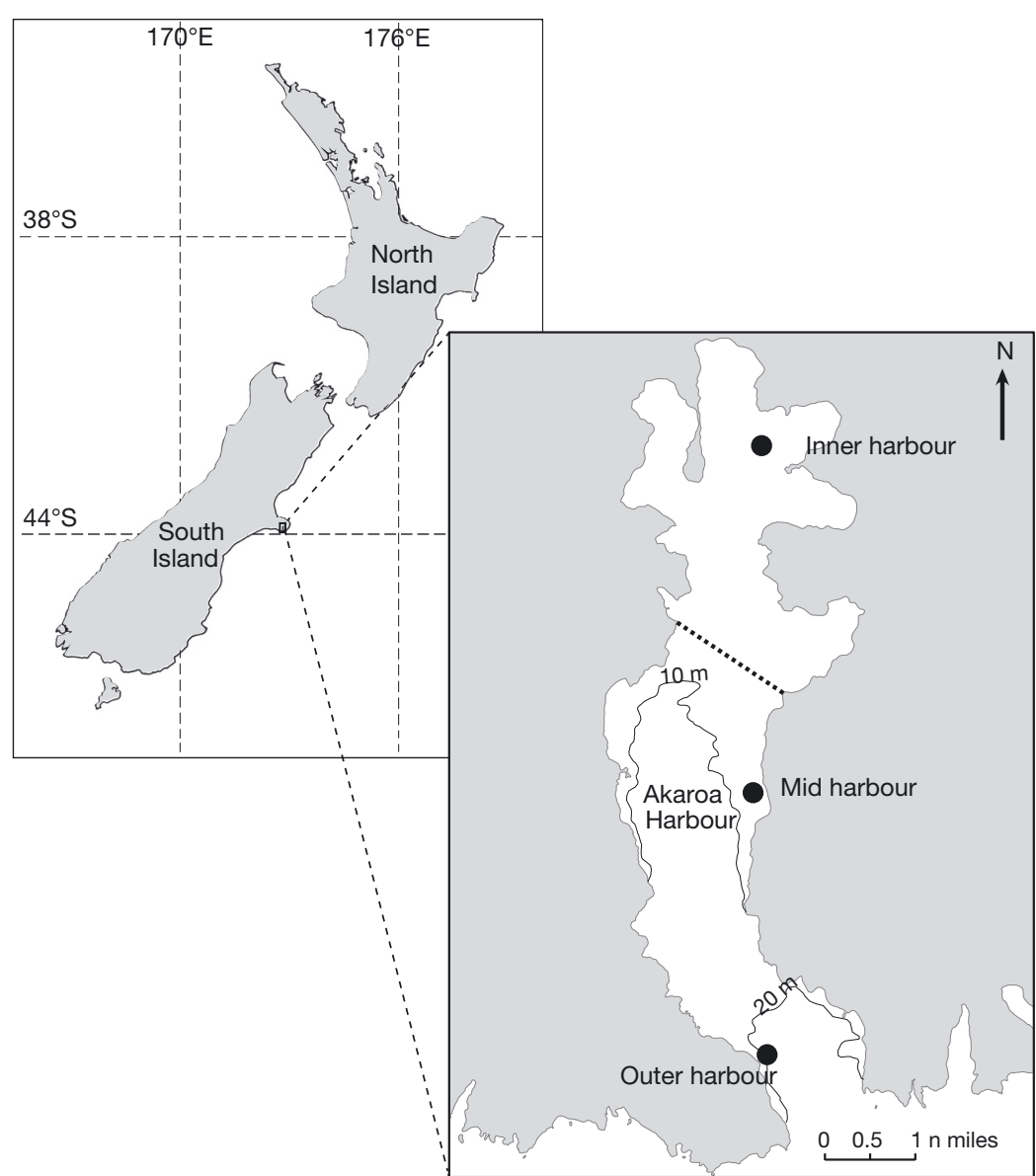

Fig. 1. Study area showing acoustic monitoring locations (@). Unattended gillnetting for flatfish by amateur fishers is legal in the area north of the dotted line from 1 April to 30 September each year

of fouling organisms, downloaded and returned to the mooring. New alkaline batteries were installed on each service.

T-PODs were set so that 5 of their 6 sequential scans were optimised to detect Hector's dolphin sonar clicks, which are narrow-band pulses centred on 120 to $130 \mathrm{kHz}$ (Dawson \& Thorpe 1990). The remaining scan was set to detect the broadband echolocation clicks characteristic of bottlenose Tursiops truncatus, dusky Lagenorhynchus obscurus and common dolphins Delphinus delphis (Au 1993, Au \& Würsig 2004, S. Dawson pers. obs.), which were the only other small cetaceans likely to use this zone. The sonar sounds of Hector's dolphin are very different from those of other inshore dolphins in New Zealand; this allows reliable discrimination of them from acoustic records (Rayment et al. 2009a). T-PODs have been used extensively with Hector's dolphins (Rayment et al. 2009a,c, 2011b). We used the same T-POD settings as Rayment et al. (2011b).
T-POD software (v.8.19; Chelonia Ltd) classifies clicks depending on the likelihood of having cetacean origin (the categories are CET HI, CET LO, DOUBTFUL, VERY DOUBTFUL and FIXED RATE/BOAT SONAR). As part of this process, any click trains having a very regular interclick interval are scored as most likely coming from an echo-sounder. In this analysis, the unit of detection was the click train (as identified by T-POD software), irrespective of how many clicks it contained. A click train was taken as being representative of an echolocation event.

Via detailed analysis of T-POD files and simultaneous recordings with a wide-band sound recording system, it has been demonstrated that T-PODs often classify genuine Hector's dolphin click trains into CET HI, CET LO and DOUBTFUL categories (Rayment et al. 2009a; for similar results with harbour porpoises see Thomsen et al. 2005). To minimise the possibility of false positives we adopted a more conservative strategy, using only click trains classified as CET HI and CET LO. Together these were classed as CET ALL.

For each acoustic detection, we calculated the number of hours after high tide and after sunrise, using data published by Land Information New Zealand (LINZ 2008) after adjusting for the length of the tidal cycle (12.42 h). We summarised these data (using a custom-written Visual Basic macro in Microsoft Excel 2008) into $12 \mathrm{~h}$ (time after high tide) $\times 24 \mathrm{~h}$ (time after sunrise) tables, one for each season within each site. Each cell in these tables represented the number of acoustic detections for a particular combination of hour after high tide and hour after sunrise for a particular site and season. Each cell, therefore, represented detections over several days. Seasons were defined following the New Zealand official (meteorological) standard as summer (1 December to 28 February), autumn (1 March to 31 May), winter (1 June to 31 August) and spring (1 September to 30 November).

Measurement of harbour areas was made using Image J (www.rsb.info.nih.gov/ij/) from Chart NZ 6324 (www.linz.govt.nz). 


\section{Modelling}

In order to model the number of detections per day, we fitted a log-linear model to the number of detections in the tables described above, with site, season, tide and time as factors in the model, and the natural logarithm of the number of observation days as an offset (McCullagh \& Nelder 2000). We assumed that the number of detections had a Poisson distribution, given the levels of the factors and the number of days. This, in turn, implies that the variance of the number of detections is equal to the mean for that combination of levels and number of days. In order to allow for overdispersion, i.e. the variance being greater than the mean, we needed to assume that the 4 -way interaction was zero, analogous to the estimation of error variance in a single-replicate factorial experiment (see, for example, Mead 1990, Section 13.5). This led to the estimate of overdispersion being calculated as $\hat{\phi}=\mathrm{X}^{2} /(\mathrm{n}-p)$, where $\mathrm{X}^{2}$ is Pearson's lack-of-fit statistic for the model containing all main effects and interactions except the 4-way interaction, $\mathrm{n}(=3456)$ is the number of cells in which detections could fall and $p(=1938)$ is the number of parameters in that particular model. We fitted all possible models (except the one containing all main effects and interactions) in R (R Core Team 2012) and compared them using quasi-Akaike's Information Criterion (QAIC) (Burnham \& Anderson 2001), which was calculated as:

$$
\mathrm{QAIC}=-\frac{2 \log \hat{L}}{\hat{\phi}}+2 p
$$

where $\hat{L}$ is the maximised value of the likelihood for that model.

To quantify differences in T-POD sensitivity we moored all 3 simultaneously on the mid-harbour mooring for $12 \mathrm{~d}$ and compared the number of detections made per day using Pearson's correlation coefficient.

\section{RESULTS}

T-POD echolocation detectors collected data over an average of $349 \mathrm{~d}$ (inner harbour: $359 \mathrm{~d}$ i mid-harbour: $336 \mathrm{~d}$; outer harbour: $354 \mathrm{~d}$ ), which represents 91 to $98 \%$ of the $368 \mathrm{~d}$ on which they were deployed. Data losses occurred due to premature battery failure, and storms which caused the loss of 1 T-POD from its mooring and the burial of a mooring and the T-POD attached to it. In both cases the instruments were recovered. The 3
T-PODs made 114675 acoustic detections in the CET ALL categories, assumed to be detections of Hector's dolphins.

Dolphins used the outer harbour site at consistently high levels throughout the year, with peak detection levels in winter (Fig. 2a). While T-PODs were operating, dolphins were detected on every day but one. In general, there was a lower detection rate at the mid-harbour site, with a weak
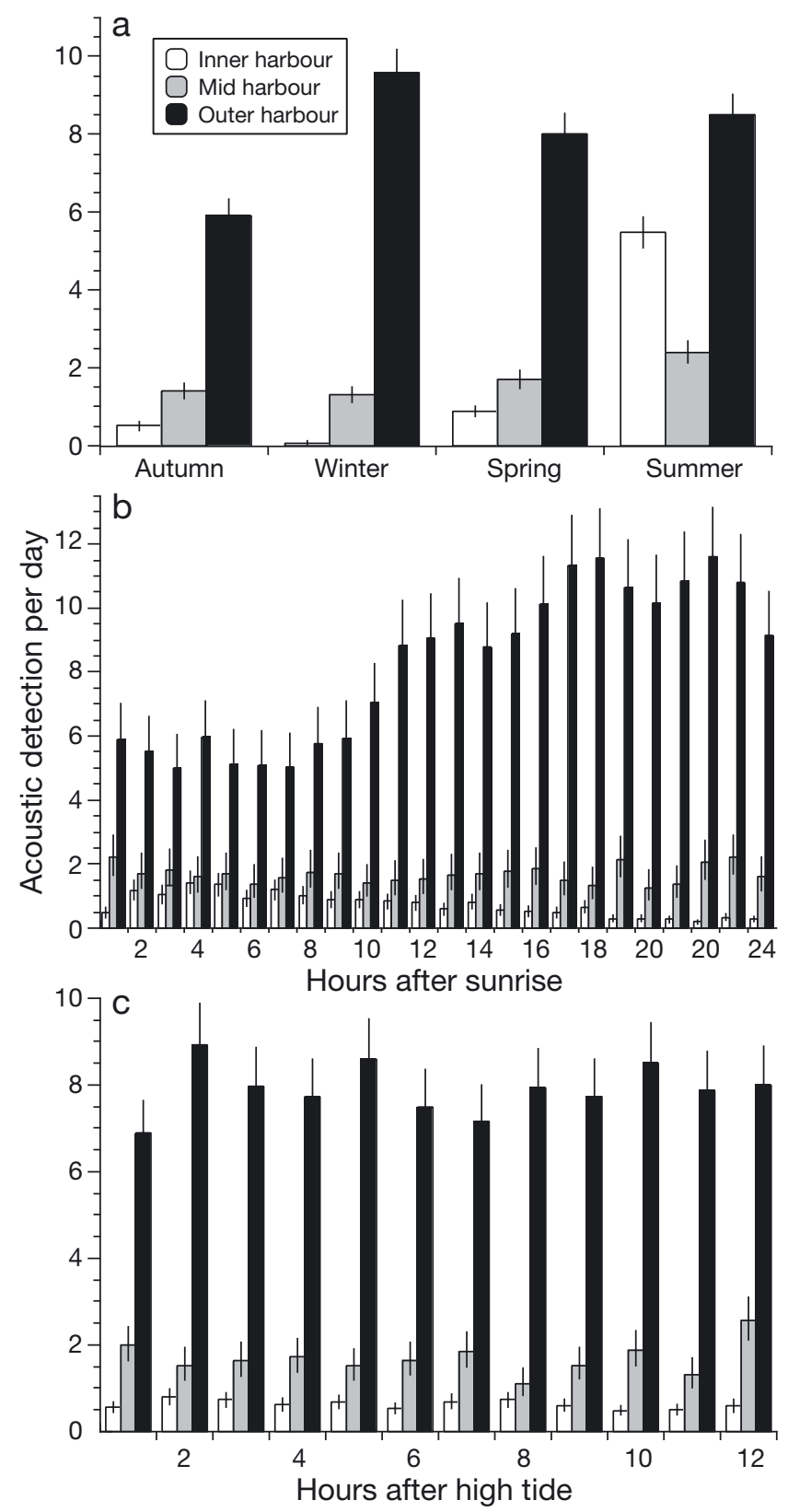

Fig. 2. Cephalorhynchus hectori. T-POD acoustic detections of click trains (a) by site and season, (b) site and time after sunrise and (c) site and time after high tide. Error bars are $95 \%$ CI 
seasonal pattern. Dolphins were detected more often in summer, but even in winter they were detected on all but 13 of the monitored days. Over the whole year, dolphins were present at the midharbour site for $>90 \%$ of the days on which the TPOD was collecting data. The strongest seasonal pattern was shown in the inner harbour, with very high detection rates in summer and low detection rates in winter. Dolphins were detected on all but $4 \mathrm{~d}$ during summer, but were only present on $32 \%$ of the monitored days in winter.

When all 3 T-PODs were attached to the same mooring, the 2 v. 4 T-PODs showed very similar performance (T-POD 488 vs. 484; Pearson's $\mathrm{r}=0.976$; total number of detections $=120$ and 113, respectively). The performance of T-POD 271 was highly correlated with the other 2 T-PODs (484 vs. $271 ; \mathrm{r}=$ $0.908 ; 488$ vs. $271, r=0.875)$, but this instrument was more sensitive, making 157 detections. There was only $1 \mathrm{~d}$, however, on which T-POD 271 was the only instrument to make a detection. In order to allow for the observed differences in sensitivity between $\mathrm{T}$ PODs 271 and 484/488 we adjusted the Poisson model as follows. The mean count for T-POD 271 was specified as $1.35 \times$ what it would have been if T-PODs 484 or 488 had been used. This is equivalent to specifying the number of days for observations with $\mathrm{T}$ POD 271 as effectively 1.35 times the actual number of days. The adjustment of 1.35 is the ratio of the total number of detections with T-POD 271 to the mean with T-PODs 484 and 488 , from the sensitivity study (157/116.5).

The best statistical model explaining habitat use included all 4 factors: 'site', 'season', 'time' (since sunrise) and 'tide' (time since high tide) and 5 interactions (site $\times$ season, site $\times$ time, site $\times$ tide, season $\times$ time, season $\times$ tide; Table 1 ). Dropping each one of the interaction terms while retaining the others, noting the resulting increase in QAIC values (Table 2), allowed interpretation of the relative importance of each interaction. The site $\times$ season interaction was by far the most important.

The next most important interaction was site $x$ time (expressed as hours after sunrise; Fig. 2b). Detection rates were fairly constant at the mid-harbour site, but showed opposite patterns at the outer and inner sites. At the inner site, detection rates were highest soon after sunrise and gradually declined during the day and into the evening. The outer harbour site showed relatively low detection rates in the morning, increasing in the late afternoon to a maximum in the late evening. This is consistent with diurnal movement of dolphins within the harbour. In summer, sunrise occurs between 05:40 and 07:00 $\mathrm{h}$, and in winter, between 07:00 and 08:00 $\mathrm{h}$ (daylight savings time). The remaining interaction (site $\times$ tide; Fig. 2c) showed no clearly interpretable pattern and was the least important of the interaction terms (Table 2).

The interactions season $\times$ tide and season $\times$ time were characterised by large confidence intervals and are difficult to interpret. There were large seasonal differences among sites (Fig. 2). When sites are combined (Fig. 3), variation due to site may act to swamp the less important effects of season versus time and tide (Fig. 3).

While there were clear seasonal differences in frequency of use of the inner harbour site (Fig. 2a), dolphins did use that area even in winter. Amateur fishers are currently permitted to set unattended gillnets for flatfish in the inner harbour from 1 April to 30 September. Dolphins were detected on the inner harbour T-POD on $41 \%$ of the days during the period when such gillnetting is legal.

Table 1. Best 6 models (of 165 fitted) as ranked via quasi-Akaike's Information Criterion (QAIC), with other representative models for comparison (in italics). Model 7 has 4 main effects and all 2-way interactions, Model 8 has all main effects and all 2-way and 3-way interactions, and Model 9 has 4 main effects only

\begin{tabular}{|c|c|c|c|c|c|c|c|c|c|c|c|c|c|c|c|c|c|}
\hline \multirow[t]{2}{*}{ Model } & \multirow{2}{*}{$\begin{array}{l} \\
\text { Site } \\
\text { (a) }\end{array}$} & \multicolumn{3}{|c|}{ - Main factors } & \multirow{2}{*}{$\mathrm{ab}$} & \multicolumn{5}{|c|}{ - 2-way interactions } & \multirow[b]{2}{*}{$\mathrm{abc}$} & \multicolumn{3}{|c|}{ 3-way interactions } & \multirow[t]{2}{*}{ QAIC } & \multirow{2}{*}{$\begin{array}{c}\text { Delta } \\
\text { AIC }\end{array}$} & \multirow[t]{2}{*}{ Weight } \\
\hline & & $\begin{array}{c}\text { Season } \\
\text { (b) }\end{array}$ & $\begin{array}{l}\text { Time } \\
\text { (c) }\end{array}$ & $\begin{array}{l}\text { Tide } \\
\text { (d) }\end{array}$ & & $\mathrm{ac}$ & $\mathrm{ad}$ & $\mathrm{bc}$ & bd & $\mathrm{cd}$ & & abd & acd & bcd & & & \\
\hline 1 & 1 & 1 & 1 & 1 & 1 & 1 & 1 & 1 & 1 & & & & & & 5034.7 & 0.0 & 0.9999 \\
\hline 2 & 1 & 1 & 1 & 1 & 1 & 1 & & 1 & 1 & & & & & & 5053.5 & 18.8 & 0.0001 \\
\hline 3 & 1 & 1 & 1 & 1 & 1 & 1 & 1 & 1 & 1 & & 1 & & & & 5058.5 & 23.8 & 0.0000 \\
\hline 4 & 1 & 1 & 1 & 1 & 1 & 1 & 1 & 1 & & & & & & & 5069.6 & 34.9 & 0.0000 \\
\hline 5 & 1 & 1 & 1 & 1 & 1 & 1 & 1 & 1 & 1 & & & 1 & & & 5074.1 & 39.4 & 0.0000 \\
\hline 6 & 1 & 1 & 1 & 1 & 1 & 1 & & 1 & 1 & & 1 & & & & 5077.6 & 42.9 & 0.0000 \\
\hline 7 & 1 & 1 & 1 & 1 & 1 & 1 & 1 & 1 & 1 & 1 & & & & & 5110.0 & 75.4 & 0.0000 \\
\hline 8 & 1 & 1 & 1 & 1 & 1 & 1 & 1 & 1 & 1 & 1 & 1 & 1 & 1 & 1 & 5837.6 & 802.9 & 0.0000 \\
\hline 9 & 1 & 1 & 1 & 1 & & & & & & & & & & & 6999.4 & 1964.7 & 0.0000 \\
\hline
\end{tabular}




\section{DISCUSSION}

Acoustic logging of echolocation activity offers round-the-clock 'listening' effort over extended periods, but, in the context of quantifying habitat use, has 2 important constraints. The first of these is that

Table 2. Relative change in QAIC on removing one 2-way interaction term. 'Figure' refers to the figure in the present paper

\begin{tabular}{|lcc|}
\hline Effect & QAIC change & Figure \\
\hline Site $\times$ season & 1316.6 & 2a \\
Site $\times$ time & 441.2 & $2 \mathrm{~b}$ \\
Season $\times$ time & 110.7 & $3 \mathrm{a}$ \\
Season $\times$ tide & 26.6 & $3 \mathrm{~b}$ \\
Site $\times$ tide & 13.1 & 2c \\
\hline
\end{tabular}

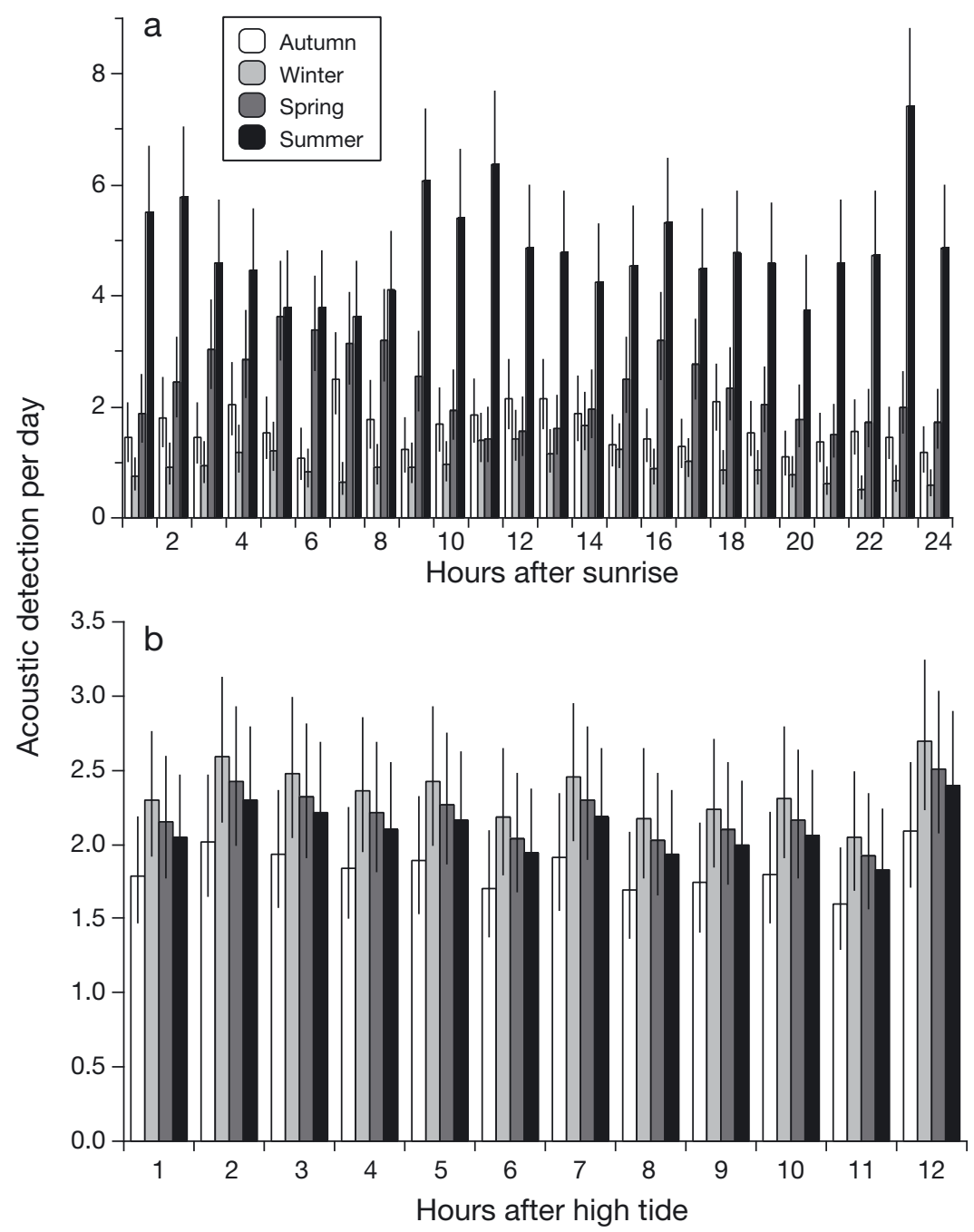

Fig. 3. Cephalorhynchus hectori. T-POD acoustic detections of click trains (a) by season and time after sunrise and (b) season and time after high tide. Error bars are $95 \%$ CI echolocation activity of small cetaceans is detectable only over relatively short ranges. Theodolite tracking of Hector's dolphins in the vicinity of a moored TPOD has shown a maximum detection distance of just over $400 \mathrm{~m}$ and an average detection distance of about $200 \mathrm{~m}$ (Rayment et al. 2009a). These estimates correspond well with estimates for harbour porpoises (Tougaard et al. 2006, Kyhn et al. 2012), which make very similar echolocation clicks, at broadly similar sound pressure levels (Morisaka et al. 2011). Even bottlenose dolphins, which can make much louder echolocation pulses (Au et al. 1974), have an average detection distance of a few hundred metres (Bailey et al. 2010, Elliott et al. 2011). The inherent directionality of sonar emissions (e.g. Au 1993) and the likelihood that dolphins are often silent (Dawson 1994, Bloom et al. 1995, Nowacek 2005, but see Verfuß et al. 2007, Akamatsu et al. 2007) further limit the chance of detection. Also, our use of the CET ALL category (in the TPOD software) was conservative, as genuine echolocation events are often classified as DOUBTFUL or VERY DOUBTFUL (Thomsen et al. 2005, Rayment et al. 2009a). Our group's work, and that of others (e.g. Thomsen et al. 2005, Bailey et al. 2010), shows that T-PODs were very conservative indicators of habitat use.

The second constraint is the assumption that acoustic detections fairly reflect dolphin presence. For this to be true, there would need to be no diel pattern in vocal activity and no consistent subdivision of the habitat into areas that are used principally for activities (such as feeding or resting), which are likely to have characteristically high or low echolocation rates. Several delphinid species do exactly this (e.g. spinner dolphins Stenella longirostris, Norris \& Dohl 1980; bottlenose dolphins, Lusseau \& Higham 2004; Risso's dolphins Grampus griseus, Visser et al. 2011). Some of those species are much less vocal in particular behaviour states (e.g. spinner dolphins while resting, Norris et al. 1994). Long-term (27 yr), intensive research at Banks Peninsula has shown no evidence of Hector's dolphins partitioning their habitat in this way. 
While several studies have examined how season, time and tide influence dolphin habitat use (e.g. Marcoux et al. 2009, dos Santos et al. 2010), few have had sufficient data to assess quantitatively the interactions among these factors and their relative importance. As indicated above, evidence of seasonal variation in habitat use is unsurprising, particularly at the small scale of this study, and has been noted in several other studies of Hector's dolphin (e.g. Dawson \& Slooten 1988, Rayment et al. 2010). Several studies have demonstrated diurnal variation in habitat use in other species. Usually this has been done using data from electronic tags (e.g. Würsig et al. 1991, Elwen et al. 2006) or via observations from a fixed point on shore (e.g. Stone et al. 1995, Bejder \& Dawson 2001). In some species this variation is obvious. Coastal spinner and dusky dolphins, for example, forage offshore in deep water at night and move into shallow nearshore waters during the day to rest and socialize (Würsig et al. 1991, Norris et al. 1994).

In Hector's dolphins, diurnal variation in habitat use is much subtler. Stone et al. (1995) interpreted their visual observations from the head of Akaroa Harbour as indicating that dolphins left the harbour at night and moved back into the harbour during the day (Stone et al. 1995). Studies in Porpoise Bay (Bejder \& Dawson 2001) and our study suggest a change in distribution with time of day, but no evidence of dolphins leaving the harbour/bay at night. In our study, detection rates were approximately constant in mid-harbour, but declined in the late evening in the inner harbour while increasing in the outer harbour. This is consistent with diurnal movement within the harbour, rather than into and out of the harbour. Acoustic monitoring of 3 bays on Banks Peninsula by Rayment et al. (2009c) showed no evidence of lower detection rates at night.

In several studies, dolphins and porpoises were more commonly observed at certain times of the tide (e.g. Mendes et al. 2002, Johnston et al. 2005a), or predominantly oriented into the tidal stream (dos Santos et al. 2010). Our model results suggest a significant effect of tide, but that this is much less important than location, season, or time. Detection rates may be slightly higher around mid-tide than at slack water in the outer harbour site (Fig. 2c), but this was not evident in the mid- or inner harbour. There is a suggestion of spring and summer showing opposite patterns in acoustic detections in the first $14 \mathrm{~h}$ after sunrise (Fig. 3a).

It is most likely that the patterns we have shown were not direct responses of the dolphins to location, season, time and tide, but responses to movements and abundance of prey potentially driven by these factors. Hector's dolphins have a catholic diet, feeding on fish and squid throughout the water column. Stomach contents from 36 South Island east coast dolphins revealed 24 prey species (Miller et al. 2012). By mass consumed, the most important species were red cod Pseudophycis bachus, sprat Sprattus sp. stargazer Crapatalus sp., arrow squid Nototadarus sp. and yellow-eyed mullet Aldrichetta forsteri (Miller et al. 2012). Trawl survey data from this region seldom cover the close inshore part of Hector's dolphin distribution (Beentjes et al. 2002), and there are no quantitative data on what prey are available to Hector's dolphins in Akaroa Harbour. Nevertheless, some of these species are known to have strongly seasonal patterns of abundance. For example, red cod was most abundant in the shallow waters of Banks Peninsula in summer, as was yellow-eyed mullet (S. Dawson \& E. Slooten pers. obs.). The latter follow a general pattern of moving into shallow inlets and harbours in spring and summer (Ayling \& Cox 1982). Arrow squid spawn in winter, and juveniles (the size eaten by Hector's dolphins) are commonly found close inshore in summer and routinely enter harbours (McKinnon 2007, J. McKinnon pers. comm. to S. Dawson).

Several prey species of Hector's dolphin have been shown to move within a harbour environment according to a diurnal/tidal cycle (Morrison et al. 2002). For example, outrigger trawls in Manukau Harbour caught yellow-eyed mullet and sole most often during nightime low tides (Morrison et al. 2002). We believe that these kinds of patterns are most likely to be the drivers of the diurnal, withinharbour change in habitat use we found in Akaroa Harbour.

Our total sample size of acoustic detections was very large $(n=114675)$. This allowed detection of very subtle effects that were not easily interpretable from the plots of interaction terms. For example, no clear patterns were evident from Figs. 2c, 3a, or 3b.

Despite having a record of catching Hector's dolphins in this location (Dawson 1991), unattended gillnetting for flatfish is legal within the inner harbour from 1 April to 30 September (Fig. 1). Acoustic monitoring showed that Hector's dolphins were in the vicinity of the T-POD on $41 \%$ of the days during which flatfish gillnetting is permitted. As explained above, this will be an underestimate of their true presence, most likely by a large margin. In addition, the area actually monitored by the T-POD was very small. Via theodolite observations of Hector's dolphin surfacing positions in the vicinity of a moored T-POD, 
Rayment et al. (2009a) showed that the effective detection radius (for click trains classified using the same criteria used here) is $198 \mathrm{~m}$. This equates to a monitored area of $0.123 \mathrm{~km}^{2}$, which is $0.82 \%$ of the area included in the concession made to amateur gillnetters. Given that the inner harbor T-POD monitored $<1 \%$ of the area in which gillnetting is legal, yet detected Hector's dolphins on $41 \%$ of the days during the 6 mo when gillnetting is legal, it is clear that Hector's dolphins use the inner harbor far more routinely than previously believed. This indicates that the current concession to gillnetters presents a substantial risk of entanglement for Hector's dolphins.

The Ministry for Primary Industries (MPI) claims to be 'absolutely committed to using the best available information to mitigate risks to Maui's and Hector's' (S. Gallacher, Deputy Director of MPI pers. comm.), yet there are several areas on the South Island coast where there is an obvious disconnect between the scientific information and the extent of protection. On the west coast, for example, comprehensive aerial surveys have shown that the dolphins' distribution extends to $6 \mathrm{n}$ miles offshore in summer and winter (Rayment et al. 2011a), yet the protection from gillnetting extends to $2 \mathrm{n}$ miles offshore, and only in summer. This region has some $74 \%$ of the total South Island population (Slooten et al. 2004). Even so, the west coast population is projected to decline under current management (Slooten \& Dawson 2010).

Nowhere, however, is the disconnect between the availability of detailed scientific information and conservation management greater than at Banks Peninsula. Hector's dolphins have been intensively studied there for almost $30 \mathrm{yr}$, and this area is the east coast stronghold for the species. Offshore distribution at Banks Peninsula has been studied via a comprehensive set of aerial surveys, flown summer and winter each year for $3 \mathrm{yr}$. These showed that in summer 19\% of the Hector's dolphin population was beyond the $4 \mathrm{n}$ mile offshore limit of protection, and in winter this increased to $56 \%$ (Rayment et al. 2010). In this contribution we have shown that the protection offered in Banks Peninsula's largest harbour does not match the data either. While dolphin survival rates have improved since the establishment of protection in 1988, this improvement is still insufficient to ensure a sustainable, let alone recovering population (Gormley et al. 2012).

Acknowledgements. This project was funded by the New Zealand Whale and Dolphin Trust. We are grateful to the Banks Peninsula Cruising Club and, in particular, to Brian Little for facilitating our use of 2 of the club's racing marks as
T-POD moorings. Daryl Coup provided a computer used to download the T-PODs, and Hamish Bowman helped us access tide and sunrise data. Will Rayment and Simon Childerhouse assisted with T-POD recovery. Will Rayment provided helpful comments on the manuscript.

\section{LITERATURE CITED}

Akamatsu T, Teilmann J, Miller L, Tougaard J (2007) Comparison of echolocation behaviour between coastal and riverine porpoises. Deep-Sea Res II 54:290-297

Akamatsu T, Nakamura K, Kawabe R, Furukawa S, Murata H, Kawakubo A, Komaba M (2010) Seasonal and diurnal presence of finless porpoises at a corridor to the ocean from their habitat. Mar Biol 157:1879-1887

$\mathrm{Au}$ WWL (1993) The sonar of dolphins. Springer-Verlag, New York, NY

$>$ Au WWL, Würsig B (2004) Echolocation signals of dusky dolphins (Lagenorhynchus obscurus) in Kaikoura, New Zealand. J Acoust Soc Am 115:2307-2313

> Au WWL, Floyd RW, Penner RH, Murchison AE (1974) Measurement of echolocation signals of the Atlantic bottlenose dolphin, Tursiops truncatus Montagu, in open waters. J Acoust Soc Am 56:1280-1290

Ayling A, Cox GT (1982) Collins guide to the sea fishes of New Zealand. Collins, Auckland

Bailey H, Thompson PM (2006) Quantitative analysis of bottlenose dolphin movement patterns and their relationship with foraging. J Anim Ecol 75:456-465

Bailey H, Thompson PM (2009) Using marine mammal habitat modelling to identify priority conservation zones within a marine protected area. Mar Ecol Prog Ser 378: 279-287

- Bailey H, Clay G, Coates EA, Lusseau D, Senior B, Thompson PM (2010) Using T-PODs to assess variations in the occurrence of coastal bottlenose dolphins and harbour porpoises. Aquat Conserv 20:150-158

Beentjes MP, Bull B, Hurst RJ, Bagley NW (2002) Demersal fish assemblages along the continental shelf and upper slope of the east coast of the South Island, New Zealand. NZ J Mar Freshw Res 36:197-223

Bejder L, Dawson S (2001) Abundance, residency, and habitat utilisation of Hector's dolphins (Cephalorhynchus hectori) in Porpoise Bay, New Zealand. NZ J Mar Freshw Res 35:277-287

Bloom PRS, Goodson AD, Klinowska M, Sturtivant CR (1995) The activities of a wild, solitary bottlenose dolphin. Aquat Mamm 21:19-42

Bonfil R, Meÿer MA, Scholl MC, Johnson R and others (2005) Transoceanic migration, spatial dynamics, and population linkages of white sharks. Science 310: 100-103

Burnham KP, Anderson DR (2001) Kullback-Leibler information as a basis for strong inference in ecological studies. Wildl Res 28:111-119

Carlström J (2005) Diel variation in echolocation behavior of wild harbor porpoises. Mar Mamm Sci 21:1-12

> Childerhouse SJ, Gales NJ (1998) Historical and modern distribution and abundance of the New Zealand sea lion Phocarctos hookeri. NZ J Zool 25:1-16

> Cox TM, Read AJ (2004) Echolocation behavior of harbor porpoises Phocoena phocoena around chemically enhanced gill nets. Mar Ecol Prog Ser 279:275-282 
Dawson SM (1991) Incidental catch of Hector's dolphin in inshore gillnets. Mar Mamm Sci 7:283-295

Dawson SM (1994) The potential for reducing entanglement of dolphins and porpoises with acoustic modifications to gillnets. Rep Int Whal Comm 15(Spec Issue):573-578

Dawson SM, Slooten E (1988) Hector's dolphin Cephalorhynchus hectori: distribution and abundance. Rep Int Whal Comm 9(Spec Issue):315-324

Dawson SM, Slooten E (1993) Conservation of Hector's dolphins: the case and process which led to establishment of the Banks Peninsula Marine Mammal Sanctuary. Aquat Conserv 3:207-221

> Dawson SM, Thorpe CW (1990) A quantitative analysis of the sounds of Hector's dolphin. Ethology 86:131-145

Dawson SM, Slooten E, DuFresne S, Wade P (2004) Smallboat surveys for coastal dolphins: line-transect surveys for Hector's dolphins (Cephalorhynchus hectori). Fish Bull 201:441-451

dos Santos UA, Alavarez MR, Schilling AC, Strenzel GMR, Le Pendu Y (2010) Spatial distribution and activities of the estuarine dolphin Sotalia guianensis (van Bénédén, 1864) (Cetacea, Delphinidae) in Pontal Bay, Ilhéus, Bahia, Brazil. Biota Neotrop 10:67-73

Elliott RG, Dawson SM, Rayment WJ (2011) Optimizing Tpod settings and testing range of detection for bottlenose dolphins in Doubtful Sound, New Zealand. J Mar Biol Assoc UK 92:1901-1907

> Elwen S, Meÿer MA, Best PB, Kotze PGH, Thornton M, Swanson S (2006) Range and movements of female Heaviside's dolphins (Cephalorhynchus heavisidii), as determined by satellite-linked telemetry. J Mammal 87: 866-877

Geertsen B, Teilmann J, Kastelein RA, Vlemmix H, Miller L (2004) Behaviour and physiological effects of transmitter attachments on a captive harbour porpoise (Phocoena phocoena). J Cetacean Res Manag 6:139-146

Gormley AM, Slooten E, Dawson SM, Barker RJ, Rayment W, DuFresne S, Brager S (2012) First evidence that marine protected areas can work for marine mammals. J Appl Ecol 49:474-480

> Ingram SN, Rogan E (2002) Identifying critical areas and habitat preferences of bottlenose dolphins Tursiops truncatus. Mar Ecol Prog Ser 244:247-255

Johnston DW, Westgate AJ, Read AJ (2005a) Effects of finescale oceanographic features on the distribution and movements of harbour porpoises Phocoena phocoena in the Bay of Fundy. Mar Ecol Prog Ser 295:279-293

> Johnston DW, Thorne L, Read AJ (2005b) Fin whales Balaenoptera physalus and minke whales Balaenoptera acutorostrata exploit a tidally driven island wake ecosystem in the Bay of Fundy. Mar Ecol Prog Ser 305:287-295

Koschinski S, Diederichs A, Amundin M (2008) Click train patterns of free-ranging harbour porpoises acquired using T-PODs may be useful as indicators of their behaviour. J Cetacean Res Manag 10:147-155

- Kyhn LA, Tougaard J, Thomas L, Duve LR and others (2012) From echolocation clicks to animal density-acoustic sampling of harbor porpoises with static dataloggers. J Acoust Soc Am 131:550-560

LINZ (Land Information New Zealand) (2008). Available at: www.linz.govt.nz/hydro/tidal-info/tidal-intro/nz-tides/ index.aspx (accessed 24 May 2009)

> Lusseau D, Higham J (2004) Managing the impacts of dolphin-based tourism through the definition of critical habitats: the case of bottlenose dolphins (Tursiops spp.) in Doubtful Sound, New Zealand. Tour Manag 25: 657-667

Marcoux M, Auger-Méthé M, Humphries MM (2009) Encounter frequencies and grouping patterns of narwhals in Koluktoo Bay, Baffin Island. Polar Biol 32: 1705-1716

Maxwell SM, Frank JJ, Breed GA, Robinson PW and others (2012) Benthic foraging on seamounts: a specialized foraging behavior in a deep-diving pinniped. Mar Mamm Sci 28:E333-E344

McCullagh P, Nelder JA (2000) Generalized linear models, 2nd edn. Chapman and Hall, London

McKinnon JF (2007) Aspects of the population biology of the southern arrow squid, Nototodarus sloanii, in southern New Zealand. PhD thesis, University of Otago, Dunedin

Mead R (1990) The design of experiments: statistical principles for practical applications. Cambridge University Press, Cambridge

Mendes S, Turrell W, Lütkebohle T, Thompson P (2002) Influence of the tidal cycle and a tidal intrusion front on the spatio-temporal distribution of coastal bottlenose dolphins. Mar Ecol Prog Ser 239:221-229

Miller E, Lalas C, Dawson S, Ratz H, Slooten E (2012) Hector's dolphin diet: the species, sizes and relative importance of prey eaten by Cephalorhynchus hectori, investigated using stomach content analysis. Mar Mamm Sci, doi:10.1111/j.1748-7692.2012.00594.x

Morisaka T, Karczmarski L, Akamatsu T, Sakai M, Dawson SM, Thornton M (2011) Echolocation signals of Heaviside's dolphins (Cephalorhynchus heavisidii). J Acoust Soc Am 129:449-457

> Morrison MA, Francis MP, Hartill BW, Parkinson DM (2002) Diurnal and tidal variation in the abundance of the fish fauna of a temperate tidal mudflat. Estuar Coast Shelf Sci 54:793-807

MPI/DOC (Ministry for Primary Industries and Department of Conservation) (2012) Review of the Maui's dolphin threat management plan: consultation paper. MPI/DOC, joint discussion paper, No. 2012/18. ISBN No: 978-0-47840083-0, ISSN No: 2253-3907. Available at: www.doc. govt.nz/getting-involved/consultations/closed/threatmanagement-plan-review-for-mauis-dolphin/consultationpaper (accessed 14 June 2013)

Norris KS, Dohl TP (1980) Behaviour of the Hawaiian spinner dolphin, Stenella longirostris. Fish Bull 77:821-849

Norris KS, Würsig B, Wells RS, Würsig M (1994) The Hawaiian spinner dolphin. University of California Press, Berkeley, CA

Nowacek DP (2005) Acoustic ecology of foraging bottlenose dolphins (Tursiops truncatus), habitat-specific use of three sound types. Mar Mamm Sci 21:587-602

Polovina JJ, Balazs GH, Howell EA, Parker DM, Seki MP, Dutton PH (2004) Forage and migration habitat of loggerhead (Caretta caretta) and olive ridley (Lepidochelys olivacea) sea turtles in the central North Pacific Ocean. Fish Oceanogr 13:36-51

R Core Team (2012) R: a language and environment for statistical computing. R Foundation for Statistical Computing, Vienna. Available at: www.R-project.org/

Rayment WJ, Dawson SM, Slooten E (2009a) Trialling an automated passive acoustic detector (T-POD) with Hector's dolphins (Cephalorhynchus hectori). J Mar Biol Assoc UK 89:1015-1022

Rayment W, Dawson S, Slooten E, Brager S, DuFresne SD, Webster TA (2009b) Kernel density estimates of along- 
shore home range of Hector's dolphins at Banks Peninsula, New Zealand. Mar Mamm Sci 25:537-556

Rayment W, Dawson S, Slooten E (2009c) Use of T-PODs for acoustic monitoring of Cephalorhynchus dolphins: a case study with Hector's dolphins in a marine protected area. Endang Species Res 10:333-339

Rayment WJ, Dawson SM, Slooten E (2010) Seasonal changes in distribution of Hector's dolphin at Banks Peninsula, New Zealand: implications for protected area design. Aquat Conserv 20:106-116

Rayment WJ, Clement D, Dawson SM, Slooten E, Secchi E (2011a) Distribution of Hector's dolphin (Cephalorhynchus hectori) off the west coast, South Island, New Zealand, with implications for the management of bycatch. Mar Mamm Sci 27:398-420

Rayment W, Dawson S, Scali S, Slooten E (2011b) Listening for a needle in a haystack: passive acoustic detection of dolphins at very low densities. Endang Species Res 14: 149-156

Schneider K, Baird RW, Dawson SM, Visser I, Childerhouse SJ (1998) Reactions of bottlenose dolphins to tagging attempts using a remotely-deployed suction-cup tag. Mar Mamm Sci 14:316-324

Slooten E, Dawson S (2010) Assessing the effectiveness of conservation management decisions: likely effects of new protection measures for Hector's dolphin (Cephalorhynchus hectori). Aquat Conserv 20:334-347

Slooten E, Dawson SM, Rayment WJ (2004) Aerial surveys for coastal dolphins: abundance of Hector's dolphins off the South Island west coast, New Zealand. Mar Mamm Sci 20:477-490

Stone G, Brown J, Yoshinaga A (1995) Diurnal patterns of movement as determined from clifftop observation. Mar Mamm Sci 11:395-402

Sveegaard S, Teilmann J, Tougaard J, Dietz R, Mouritsen

Editorial responsibility: Andrew Read,

Beaufort, North Carolina, USA
KN, Desportes G, Siebert U (2011) High-density areas for harbor porpoises (Phocoena phocoena) identified by satellite tracking. Mar Mamm Sci 27:230-246

Thomsen F, Van Elk N, Brock V, Piper W (2005) On the performance of automated porpoise-click-detectors in experiments with captive harbor porpoises (Phocoena phocoena). J Acoust Soc Am 118:37-40

Tougaard J, Poulsen LR, Amundin M, Laresen F, Hansen JR, Teilman J (2006) Detection function of T-PODs and estimation of porpoise densities. In: Leeney $\mathrm{RH}$, Tregenza NJC (eds) Proc Workshop Static Acoustic Monitoring of Cetaceans, 20th Annu Meeting European Cetacean Society, Gdynia, 2 Apr 2006. ECS Newsl 46:7-14

Tougaard J, Carstensen J, Teilmann J, Skov H, Rasmussen P (2009) Pile driving zone of responsiveness extends beyond $20 \mathrm{~km}$ for harbor porpoises (Phocoena phocoena (L.)). J Acoust Soc Am 126:11-14

> Verfuß U, Honnef CG, Meding A, Dähne M, Mundry R, Benke $H$ (2007) Geographical and seasonal variation of harbour porpoise (Phocoena phocoena) presence in the German Baltic Sea revealed by passive acoustic monitoring. J Mar Biol Assoc UK 87:165-176

> Visser F, Hartman KL, Rood EJJ, Hendriks AJE and others (2011) Risso's dolphins alter daily resting pattern in response to whale watching at the Azores. Mar Mamm Sci 27:366-381

> Wilson B, Thompson PM, Hammond PS (1997) Habitat use by bottlenose dolphins: seasonal distribution and stratified movement patterns in the Moray Firth, Scotland. J Appl Ecol 34:1365-1374

Würsig B, Cipriano F, Würsig M (1991) Dolphin movement patterns (information from radio and theodolite tracking studies). In: Pryor K, Norris K (eds) Dolphin societies discoveries and puzzles. University of California Press, Berkeley, CA, p 78-90

Submitted: December 20, 2012; Accepted: March 11, 2013 Proofs received from author(s): June 14, 2013 